\title{
Tracking the origin and dispersion of contaminated sediments transported by rivers draining the Fukushima radioactive contaminant plume
}

\author{
HUGO LEPAGE ${ }^{1}$, OLIVIER EVRARD ${ }^{1}$, YUICHI ONDA ${ }^{2}$, \\ CAROLINE CHARTIN ${ }^{1}$, IRENE LEFEVRE ${ }^{1}$, AYRAULT SOPHIE ${ }^{1} \&$ \\ PHILIPPE BONTE ${ }^{1}$
}

1 Laboratoire des Sciences du Climat et de l'Environnement (CEA, CNRS,UVSQ), F-91198 Gif-sur-Yvette France hugo.lepage@1sce.ipsl.fr

2 Center for Research in Isotopes and Environmental Dynamics (CRIED), Tsukuba University, Tsukuba, Japan

\begin{abstract}
This study was conducted in several catchments draining the main Fukushima Dai-ichi Power Plant contaminant plume in Fukushima prefecture, Japan. We collected soils and sediment drape deposits $(\mathrm{n}=128)$ and investigated the variation in ${ }^{137} \mathrm{Cs}$ enrichment during five sampling campaigns, conducted every six months, which typically occurred after intense erosive events such as typhoons and snowmelt. We show that upstream contaminated soils are eroded during summer typhoons (June-October) before being exported during the spring snowmelt (March-April). However, this seasonal cycle of sediment dispersion is further complicated by the occurrence of dam releases that may discharge large amounts of contaminants to the coastal plains during the coming years.
\end{abstract}

Key words erosion; sediment; soil; Fukushima; radio-caesium; enrichment factor

\section{INTRODUCTION}

The Tohoku earthquake and the subsequent tsunami that occurred on 11 March 2011 impacted the Fukushima Dai-Ichi Nuclear Power Plant (FDNPP) and led to a significant atmospheric release of radionuclides such as ${ }^{137} \mathrm{Cs}\left(\mathrm{T}_{1 / 2}=30\right.$ years $)$. About $80 \%$ of the release was transported out and over the Pacific Ocean, with the rest primarily deposited on the soils of Fukushima Prefecture as a result of wet atmospheric fallout. Estimations of ${ }^{137} \mathrm{Cs}$ activity, as a result of the fallout, range between $10 \mathrm{PBq}$ and $760 \mathrm{PBq}$ (Koo et al. 2014); the deposits formed a radioactive plume covering an area of $3000 \mathrm{~km}^{2}$ and within which contamination exceeds $300 \mathrm{KBq} / \mathrm{m}^{2}$. Radiocaesium is known to have a low mobility in soils and to be rapidly fixed to the finest particles, especially to clay minerals (Sawiiney 1972; He \& Walling, 1996; Kamei-ishikawa et al., 2008; Koarashi et al., 2012). In the vicinity of the main contaminant plume, it was reported that most of the ${ }^{137} \mathrm{Cs}$ remained in the upper first centimetre of the soil (Fujiwara et al., 2012; Kato et al., 2012; Koarashi et al., 2012; Nakanishi et al., 2013; Lepage et al., 2014).

The Fukushima region is affected by severe erosion events triggered by typhoons or snowmelt, which preferentially erode and supply fine sediment to coastal rivers (Walling \& Woodward, 1992; Motha et al., 2002). These events have led to an increase in radiocaesium concentrations measured in suspended matter transiting local rivers (Fukuyama et al., 2005; Nagao et al., 2013; Ueda et al., 2013; Mouri et al., 2014; Yamashiki et al., 2014; Yoshikawa et al., 2014). These catchments display seasonal cycles of sediment dispersion. First, intense rainfall and typhoons taking place during the rainy season (July-October) mainly lead to the local erosion of contaminated soil. Then, the spring snowmelt exports the radioactive material to the coastal plains, especially the finest and the most contaminated particles (Chartin et al., 2013; Evrard et al., 2013). Unfortunately, continuous river monitoring was only operational in part of the area draining the contaminant plume; e.g. in the Abukuma River basin $\left(5172 \mathrm{~km}^{2}\right)$. In this area, it was estimated that more than $60 \%$ of the total radiocaesium flux was transported during typhoon Roke (September 2011; Yamashiki et al., 2014).

In the absence of continuous monitoring along the coastal rivers draining the most contaminated part of the plume, alternative techniques had to be developed to track the dispersion of radioactive material and their potential supply to the Pacific Ocean. This export to coastal water has been put forward by previous studies (Chartin et al., 2013; Nagao et al., 2013), and may partly explain the constant elevated levels of contamination recorded in various marine species close to the FNDDP. 
Additionally, the constant liquid releases of radionuclides at FDNPP have also contributed to coastal contamination (Buesseler et al., 2012; Tateda et al., 2013)

To document the dispersion of radioactive contamination in these coastal rivers, we collected soils and sediment drape deposits at several locations along these rivers after the main erosive events that occurred between 2011 and 2013, and investigated their impact on the concentration and distribution of radiocaesium.

\section{MATERIALS AND METHODS}

\section{Study area}

The study was conducted in the Fukushima Prefecture, located in Northeastern Japan, $30 \mathrm{~km}$ to the northwest of the FDNPP (Fig. 1). We focused our work on three coastal catchments (Mano, Nitta and Ota, $530 \mathrm{~km}^{2}$ ) draining the main part of the radioactive plume. These catchments extend from the coastal mountain range (approximately $30 \mathrm{~km}$ from the coast) to the Pacific Ocean, and their elevation ranges from 0 to $900 \mathrm{~m}$. Dams are present along the three catchments but mostly impact the Mano and Ota rivers as the dams in Nitta catchment are not in the main river channel.

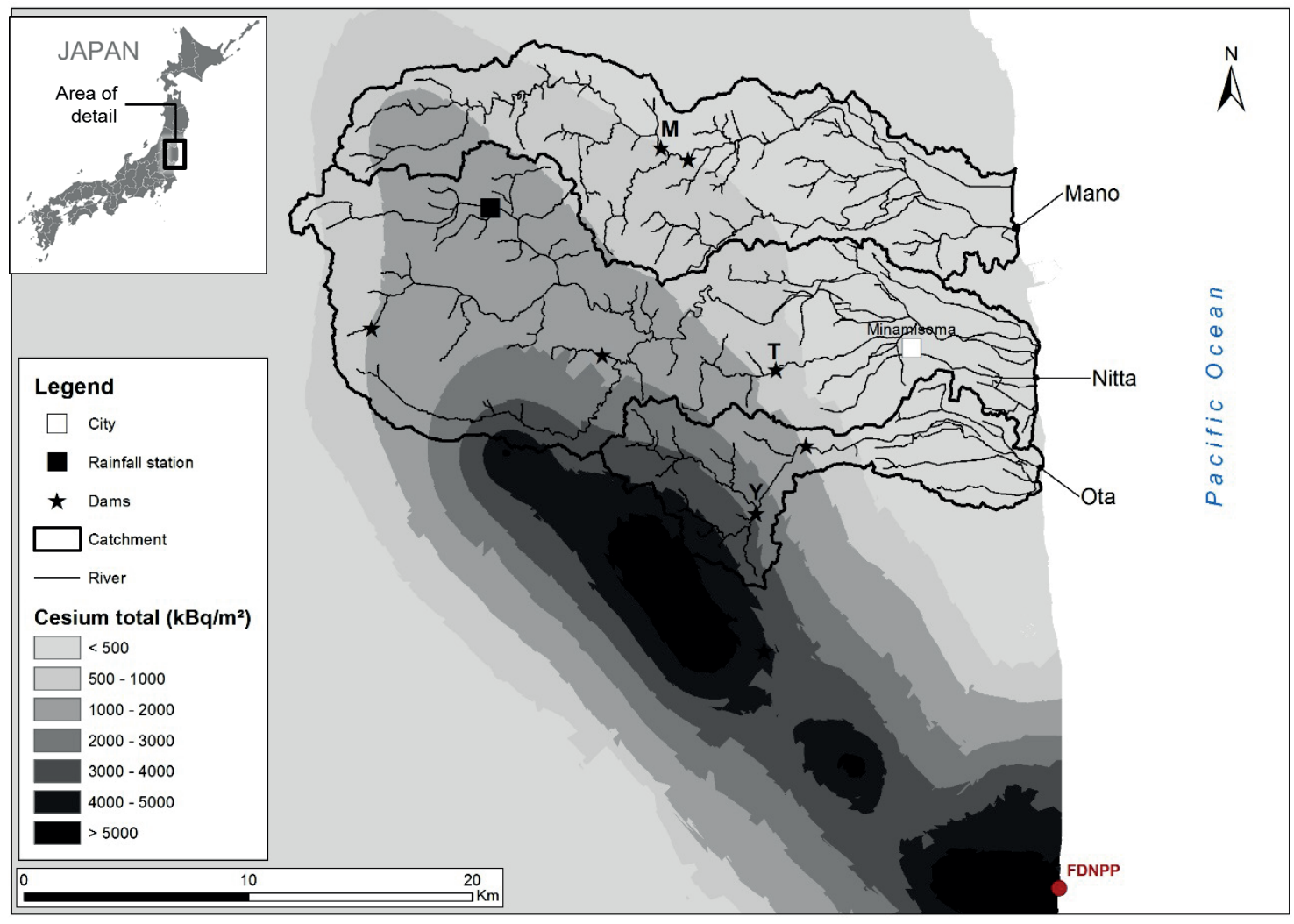

Fig. $1{ }^{134} \mathrm{Cs}+{ }^{137} \mathrm{Cs}$ soil inventory recalculated to the date of 14 June 2011 based on MEXT data (2012) in the three study catchments (Mano, Nitta and Ota). FDNPP stands for Fukushima Dai-ichi Nuclear Power Plant, M for Mano dam, T for Takanokura dam and Y for Yokokawa dam.

\section{Sample collection}

Sampling was conducted after the main erosive periods of the year (i.e. summer typhoons and spring snowmelt) between November 2011 and November 2013 (Table 1; Fig. 2).

The soil samples actually represent composites of from five to ten subsamples from randomly selected locations collected using a non-metallic trowel along the three rivers. In addition, sediment drape deposits were collected, as they are likely to integrate sediment from the last 
Table 1 Summary of the fieldwork (FW) campaigns and the rainfall characteristics recorded during the study period.

\begin{tabular}{llllll}
\hline FW & Date & Main erosive event & $\begin{array}{l}\text { Rainfall max } \\
\left(\mathrm{mm} \mathrm{h}^{-1}\right)\end{array}$ & $\begin{array}{l}\text { Total rainfall until } \\
\text { next event }(\mathrm{mm})\end{array}$ & $\begin{array}{l}\text { Soil/sediment } \\
\text { collected }\end{array}$ \\
\hline 1 & Nov. 2011 & Typhoon (Songda) & 31 & 920 & $12 / 16$ \\
2 & April 2012 & Typhoon (Roke) & 5 & 268 & $17 / 23$ \\
3 & Nov. 2012 & Strong rainfall & 27 & 945 & $21 / 29$ \\
4 & May 2013 & Snowmelt & 8 & 329 & $5 / 29$ \\
5 & Nov. 2013 & $\begin{array}{l}\text { Tropical storm (Man-Yi) } \\
\text { Typhoon (Wipha) }\end{array}$ & 36 & 845 & $13 / 31$ \\
\hline
\end{tabular}

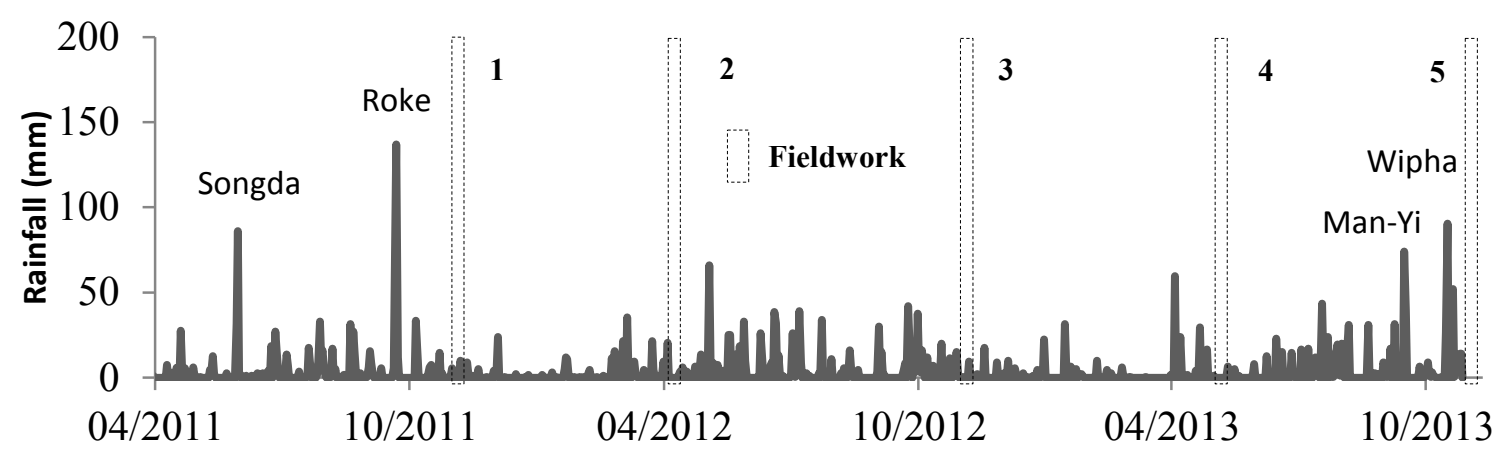

Fig. 2 Rainfall data provided by the Japan Meteorological Agency (JMA) with indication of the main rainfall events and the organization of fieldwork campaigns.

hydro-sedimentary events of low to intermediate magnitude (Evrard et al., 2011). Sediment drape deposits were selected as an alternative to the in-stream sampling of suspended sediment to increase the spatial coverage of the survey within the catchments, and to avoid the logistical problems associated with the collection of suspended sediment in river catchments affected by typhoons. Olley et al. (2013) demonstrated that drape deposits and suspended sediment sampled by time-integrated samplers were not significantly different. We randomly collected five to ten subsamples to obtain representative samples that were likely to have been deposited after the last major flood. Sediment drape deposits will be referred to as sediment in the remainder of the text.

\section{Gamma spectrometry measurements}

Before measurement, samples were dried at $40^{\circ} \mathrm{C}$ for a week, ground to a fine powder, and then packed into $15 \mathrm{~mL}$ polyethylene specimen cups. ${ }^{137} \mathrm{Cs}$ activities in all samples were determined by gamma spectrometry using very low-background coaxial $\mathrm{N}$ - and P-type HPGe detectors (Canberra/Ortec). Counting times for samples varied between $80000 \mathrm{~s}$ and $150000 \mathrm{~s}$. The ${ }^{137} \mathrm{Cs}$ activities were measured at the $661 \mathrm{keV}$ emission peak. Counting efficiencies and quality assurance were monitored using internal and certified International Atomic Energy Agency (IAEA) reference materials prepared in the same specimen cups as the samples. Analytical imprecision was estimated by combining counting statistics and calibration uncertainties. Summing and self-absorption effects were taken into account by analysing standards with similar densities and characteristics as the collected samples. All activities were decay corrected to the date of 14 March 2011, corresponding to the date of the first radionuclide deposits on soils (Kinoshita et al., 2011; Shozugawa et al., 2012).

\section{Enrichment factor}

The ${ }^{137} \mathrm{Cs}$ enrichment factor (EF) in sediment was calculated as follows:

$$
E F=\frac{{ }^{137} \mathrm{Cs} \text { activity in riverine sediment }\left(\mathrm{Bq} \mathrm{kg}^{-1}\right)}{{ }^{137} \mathrm{Cs} \text { activity in soil }\left(\mathrm{Bq} \mathrm{kg}^{-1}\right)}
$$

Enrichment factors are widely used to calculate the magnitude of metallic contamination compared 
to the local background signal (Ayrault et al., 2010). In this study, we used it to investigate whether there was an increase or a decrease in ${ }^{137} \mathrm{Cs}$ contamination in coastal rivers.

\section{RESULTS AND DISCUSSION}

Sampling locations situated in the upstream part of the Mano catchment were characterized by a low radiocaesium enrichment factor throughout the entire study period (Fig. 3), reflecting a higher contamination in soil than in sediment. This could be explained by several processes:

- Contaminated sediment was massively exported during the 2011 typhoons;

- As this area is mainly covered by evergreen forests (Fig. 4), erosion processes are limited as litter provides a dense and thick vegetative cover that protected the soils (Koarashi et al. 2012; Matsunaga et al. 2013). In addition, paddy fields were abandoned and densely covered by vegetative regrowth (Fig. 4) that strongly reduced erosive processes (Valentin et al., 2008; Vasquez-Mendez et al., 2010).

- Bank erosion supplied subsurface material depleted in radiocaesium to the rivers, as confirmed by gamma spectrometry measurements conducted on subsurface material (mean $=50 \mathrm{~Bq} \mathrm{~kg}^{-1}$ for 3 samples - not presented in this paper) that diluted the contaminated sediment conveyed by rivers in this area.

The upstream part of the Ota River catchment is mainly covered by broadleaf forests located on steep hillslopes (Fig. 4), so that soils were rapidly eroded, and contaminated particles were exported and stored behind the Yokokawa dam (Fig. 1; Chartin et al., 2013).
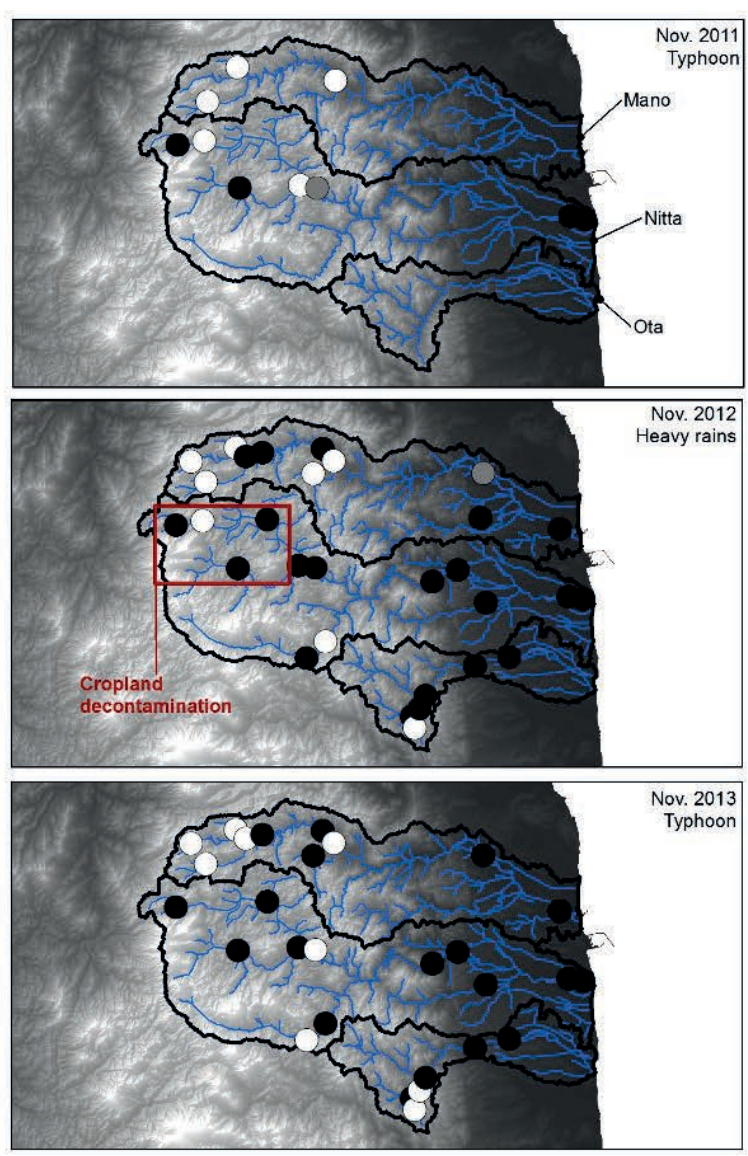
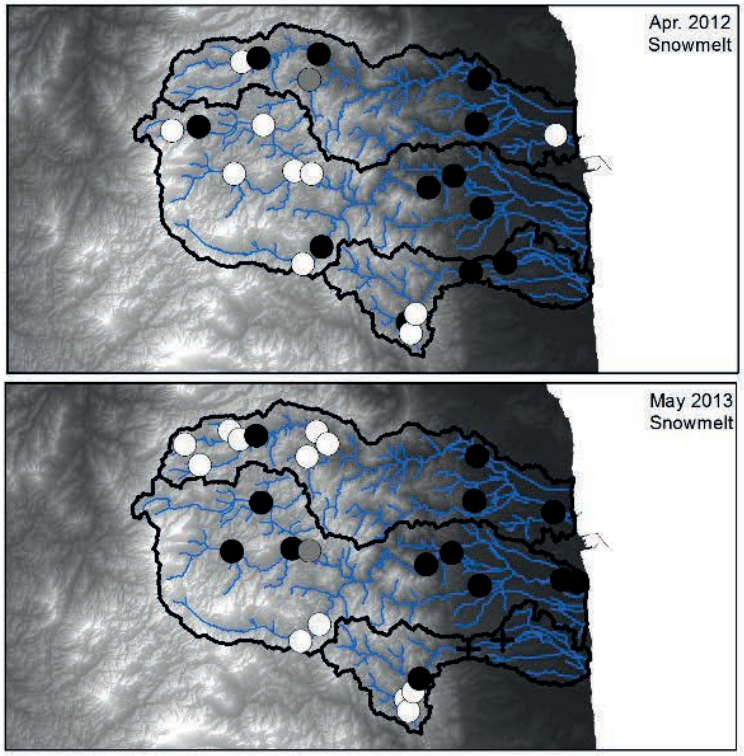

\section{Enrichment factor}

Elevation

$+\quad$ No fresh sediment deposit

$0<0.9$

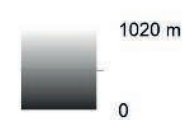

$0.9-1.1$

$>1.1$

Fig. 3 Evolution of radiocaesium enrichment factor along rivers in the three study catchments during the five fieldwork campaigns. The red square indicates the part of the Nitta catchment where decontamination works were under progress during autumn in 2013. 

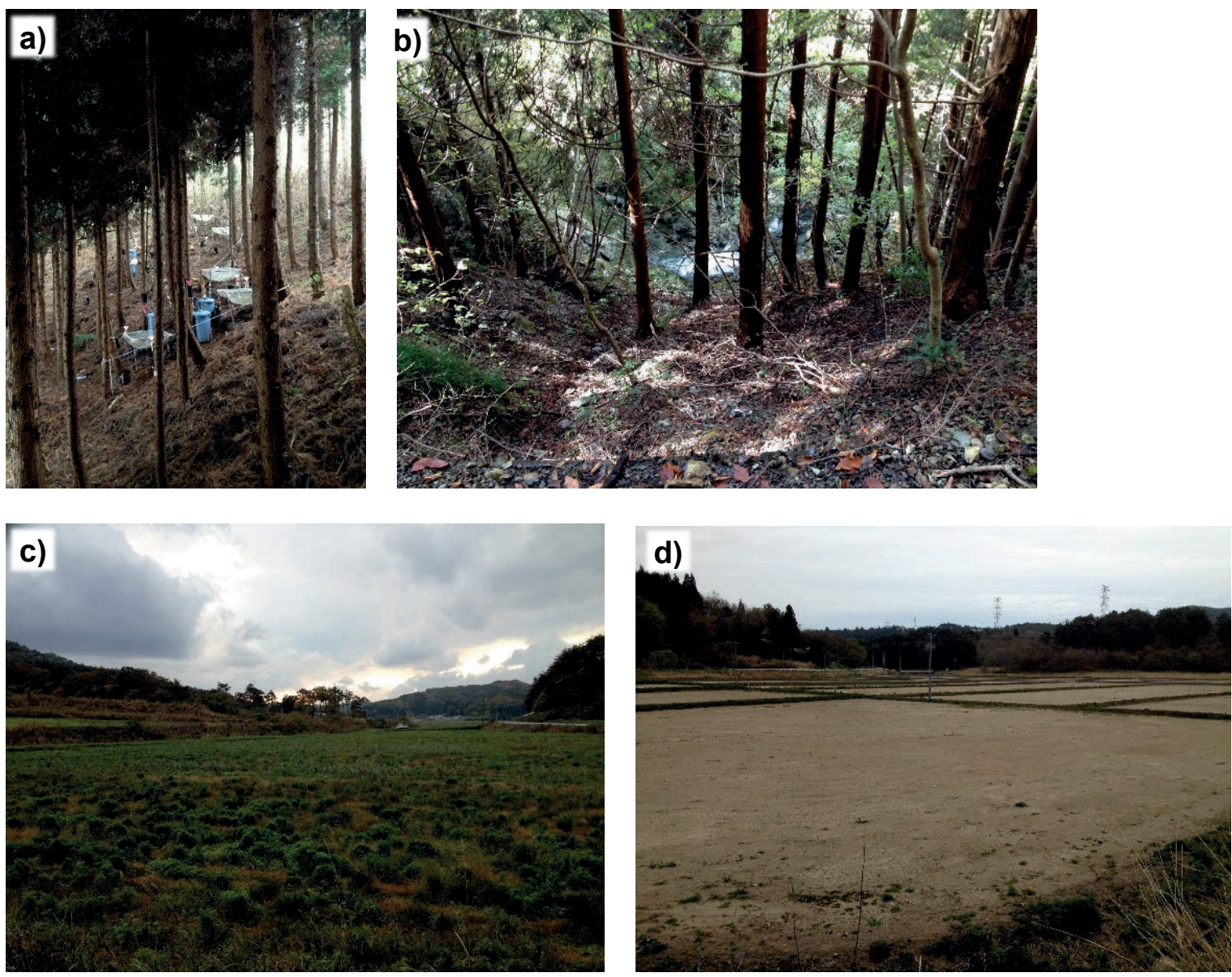

Fig. 4 (a) Evergreen forest with thick and dense litter cover of the soil (as observed in upper parts of the Mano catchment), (b) broadleaf forest on steep slopes within the Ota catchment, (c) abandoned paddy field in Mano catchment, and (d) decontaminated paddy field in the Nitta catchment.

The erosive behaviour observed in the upper parts of the Nitta catchment was different, as contaminated material was continuously supplied to the rivers; this pattern is reflected in the higher number of monitoring points characterised by EF $>1.1$ collected throughout the study (Fig. 3). Remediation efforts, mainly initiated during the autumn of 2013, also may partly explain the almost continuous supply of contaminated soil to the rivers (Fig. 4). However, the results obtained on material collected in the upper part of the Nitta catchment prior to the autumn of 2013 (before decontamination) tended to display EFs $<0.9$.

The succession of typhoons that caused intense soil erosion, and the snowmelt events that led to the export of contamination to the coastal plains, is illustrated in Fig. 5. As previously mentioned, this figure illustrates the increase in the number of sampling sites with EFs $>1.1$ after heavy rainfall events (November 2012 and 2013) whereas it also displays a decrease in the number of sampling sites with EFs $>1.1$ after snowmelt events that probably reflect occurrences of flushes of radioactive material to the coastal plains (April 2012 and May 2013).

Results obtained in the coastal plains show a different trend - a slow decrease of contamination within the coastal river systems until May 2013 (Fig. 5). This behaviour is likely explained by the progressive and continuous export of radioactive material to the Pacific Ocean. The lower values recorded after snowmelt events (80-89\%) as compared to after the typhoons (95-100\%) could be explained by a different behaviour, depending on whether the river is dammed (Mano and Ota rivers) or not (Nitta River), as export to the coastal plain is reduced by the dams during snowmelt. Also, the large increase in contaminated material recorded during the November 2013 campaign (Fig. 5) may be explained by the joint occurrence of dam releases (Fukushima River Basin Comprehensive 


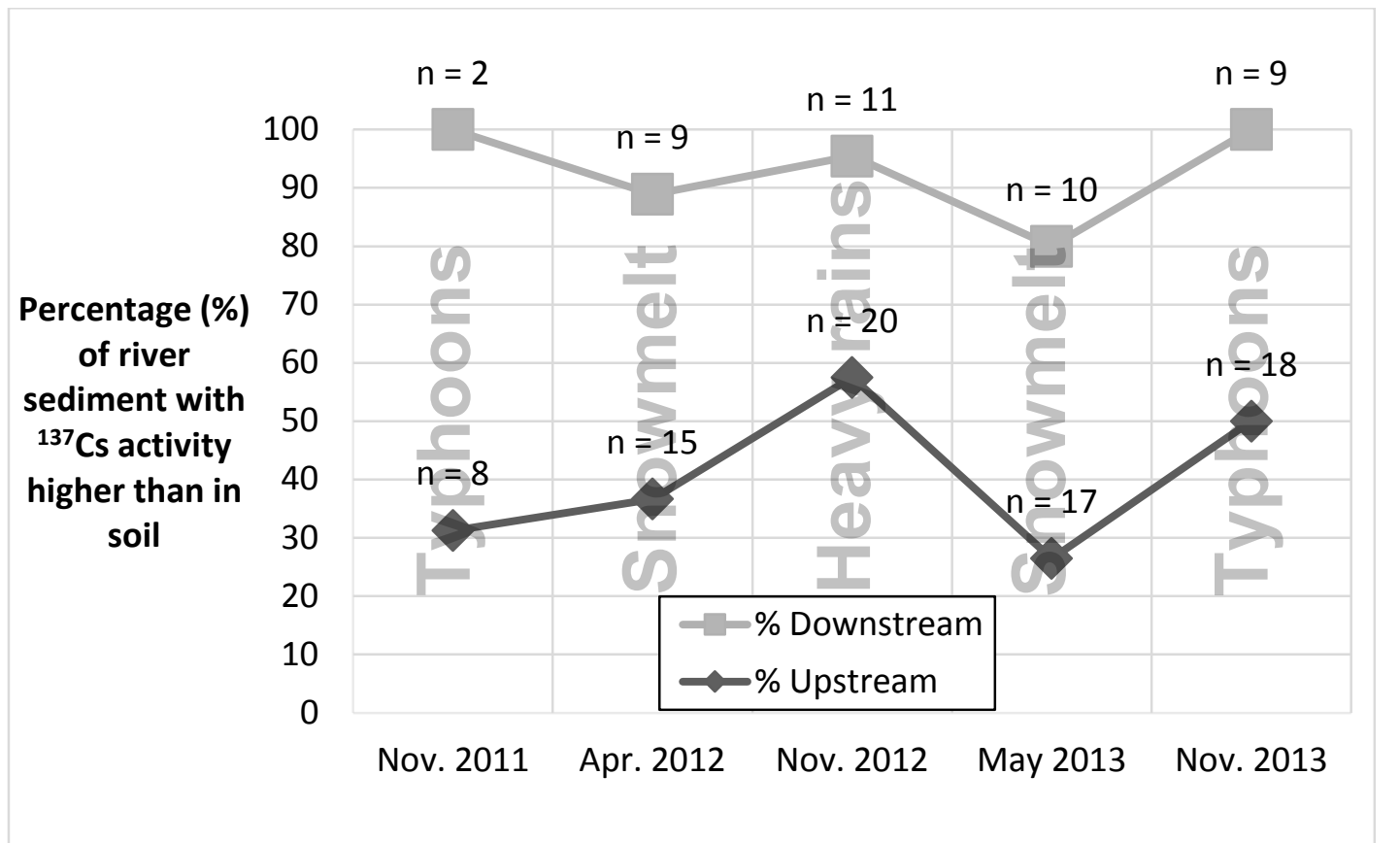

Fig. 5 Evolution of the percentage of sampling sites where radiocaesium activities measured in sediment drape deposits were higher than on nearby soils between November 2011 and November 2013. n stands for number of samples.

Information System 2013), and large-scale decontamination works in paddy fields located in the upper parts of the free-flowing Nitta River catchment (Fig. 4).

\section{CONCLUSIONS}

We investigated the dispersion of radioactive material from the main contaminant plume along Fukushima coastal rivers by calculating the evolution in the ${ }^{137} \mathrm{Cs}$ enrichment factor at different locations within the catchments. We showed that in parts of the upper catchments, the supply of contaminated material to the rivers was controlled by the occurrence of typhoons that led to local soil erosion, and by snowmelt events that exported the contaminants to the coastal plains. In contrast, contamination in downstream parts of these catchments showed a slow decrease, despite the potential for the continuous export of radioactive material to the Pacific Ocean. The joint occurrence of violent typhoons and dam releases in 2013 led to a general increase in the contaminant levels measured across the catchments.

Ongoing and future work will aim to model and quantify the contaminant fluxes to the Ocean, and the respective contributions of typhoons and snowmelt events to the dispersion of contaminated material.

Acknowledgements This work has been supported by ANR and JST in the framework of the joint TOFU ANR Flash/J-RAPID Franco-Japanese project (ANR-11-JAPN-001), and by CEA (Direction des Relations Internationales) and UVSQ (Bonus de Qualité Internationale) grants. This work has also been supported by CNRS in the framework of the NEEDS-Environnement HAMUSUTA project, and by the Institute of Environmental Radioactivity in Fukushima University. Finally, funding from ANR in the framework of the AMORAD project (ANR-11-RSNR-0002) is gratefully acknowledged. Hugo Lepage received a PhD fellowship from CEA (Commissariat à l'Energie Atomique et aux Energies Alternatives).

\section{REFERENCES}

Ayrault, S., et al. (2010) Silver and thallium historical trends in the Seine River basin. J. Environ. Monit. 12, 2177-85. Buesseler, K.O.K., et al. (2012) Fukushima-derived radionuclides in the ocean and biota off. Japan. Proc. 5984-5988, 1-7. 
Chartin, C., et al. (2013) Tracking the early dispersion of contaminated sediment along rivers draining the Fukushima radioactive pollution plume. Anthropocene 1, 23-34.

Evrard, O., et al. (2011) Combining suspended sediment monitoring and fingerprinting to determine the spatial origin of fine sediment in a mountainous river catchment. Earth Surf. Process. Landforms 36, 1072-1089.

Evrard, O., et al. (2013) Evolution of radioactive dose rates in fresh sediment deposits along coastal rivers draining Fukushima contamination plume. Sci. Rep. 3, 3079.

Fujiwara, T., Saito, T., Muroya, Y. (2012) Isotopic ratio and vertical distribution of radionuclides in soil affected by the accident of Fukushima Dai-ichi nuclear power plants. J. Environ. Radioact. 113, 37-44.

Fukushima River Basin Comprehensive Information System (2013) http://kaseninf.pref.fukushima.jp/gis/

Fukuyama, T., Takenaka, C. and Onda, Y. (2005) ${ }^{137} \mathrm{Cs}$ loss via soil erosion from a mountainous headwater catchment in central Japan. Sci. Total Environ. 350, 238-47.

$\mathrm{He}, \mathrm{Q}$. and Walling, D. (1996) Interpreting particle size effects in the adsorption of ${ }^{137} \mathrm{Cs}$ and unsupported $210 \mathrm{~Pb}$ by mineral soils and sediments. J. Environ. Radioact. 30, 117-137.

Kamei-Ishikawa, N., Uchida, S. and Tagami, K. (2008) Distribution coefficients for $85 \mathrm{Sr}$ and ${ }^{137}$ Cs in Japanese agricultural soils and their correlations with soil properties. J. Radioanal. Nucl. Chem. 277, 433-439.

Kato, H., Onda, Y. and Teramage, M. (2012) Depth distribution of ${ }^{137} \mathrm{Cs},{ }^{134} \mathrm{Cs}$, and $131 \mathrm{I}$ in soil profile after Fukushima Daiichi Nuclear Power Plant Accident. J. Environ. Radioact. 111, 59-64.

Kinoshita, N., et al. (2011) Assessment of individual radionuclide distributions from the Fukushima nuclear accident covering central-east Japan. Proc. Natl. Acad. Sci. U. S. A. 108, 19526-9.

Koarashi, J., et al. (2012) Factors affecting vertical distribution of Fukushima accident-derived radiocesium in soil under different land-use conditions. Sci. Total Environ. Environ. 431, 392-401.

Koo, Y.-H., Yang, Y.-S. and Song, K.-W. (2014) Radioactivity release from the Fukushima accident and its consequences: A review. Prog. Nucl. Energy 74, 61-70.

Lepage, H., et al. (2014) Environmental mobility of 110mAg: lessons learnt from Fukushima accident (Japan) and potential use for tracking the dispersion of contamination within coastal catchments. J. Environ. Radioact. 130, 44-55.

Matsunaga, T., et al. (2013) Comparison of the vertical distributions of Fukushima nuclear accident radiocesium in soil before and after the first rainy season, with physicochemical and mineralogical interpretations. Sci. Total Environ. Environ. 447C, $301-314$. Ministry of Education, Culture, Sports, Science and Technology
http://radioactivity.nsr.go.jp/ja/contents/7000/6289/24/203_0928.pdf

Motha, J.A. and Wallbrink, P. (2002) Tracer properties of eroded sediment and source material. Hydrol. Process. 16, $1983-2000$.

Mouri, G., et al. (2014) Assessment of the caesium ${ }^{-137}$ flux adsorbed to suspended sediment in a reservoir in the contaminated Fukushima region in Japan. Environ. Pollut. 187C, 31-41.

Nagao, S., et al. (2013) Export of ${ }^{134} \mathrm{Cs}$ and ${ }^{137} \mathrm{Cs}$ in the Fukushima river systems at heavy rains by Typhoon Roke in September 2011. Biogeosciences 10,6215-6223.

Nakanishi, T., et al. (2013) $\left({ }^{137}\right)$ Cs vertical migration in a deciduous forest soil following the Fukushima Dai-ichi Nuclear Power Plant accident. J. Environ. Radioact. $128 \mathrm{C}, 9-14$.

Olley, J., et al. (2013) Subsoil erosion dominates the supply of fine sediment to rivers draining into Princess Charlotte Bay, Australia. J. Environ. Radioact. 124C, 121-129.

Sawi-iney, B., 1972. Selective sorption and fixation of cations by clay minerals: a review. Clays Clay Miner. 20, 93-100.

Shozugawa, K., Nogawa, N. and Matsuo, M., (2012) Deposition of fission and activation products after the Fukushima Dai-ichi nuclear power plant accident. Environ. Pollut. 163, 243-7.

Tateda, Y., Tsumune, D. and Tsubono, T. (2013) Simulation of radioactive cesium transfer in the southern Fukushima coastal biota using a dynamic food chain transfer model. J. Environ. Radioact. 124, 1-12.

Ueda, S., et al. (2013) Fluvial discharges of radiocaesium from watersheds contaminated by the Fukushima Dai-ichi Nuclear Power Plant accident, Japan. J. Environ. Radioact. 118, 96-104.

Valentin, C., et al. 2008. Runoff and sediment losses from 27 upland catchments in Southeast Asia: Impact of rapid land use changes and conservation practices. Agric. Ecosyst. Environ. 128, 225-238.

Vásquez-Méndez, R., et al. (2010) Soil erosion and runoff in different vegetation patches from semiarid Central Mexico. Catena $80,162-169$.

Walling, D. and Woodward, J. (1992) Use of radiometric fingerprints to derive information on suspended sediment sources, in: Erosion and Sediment Transport Monitoring Programmes in River Basins. Oslo, pp. 153-164.

Yamashiki, Y., et al. (2014) Initial flux of sediment-associated radiocesium to the ocean from the largest river impacted by Fukushima Daiichi Nuclear Power Plant. Sci. Rep. 4, 3714.

Yoshikawa, N., et al. (2014) ${ }^{137} \mathrm{Cs}$ in irrigation water and its effect on paddy fields in Japan after the Fukushima nuclear accident. Sci. Total Environ. 481, 252-259. 